\title{
Hall v. Nevada: State Court Jurisdiction Over Sister States v. American State Sovereign Immunity
}

\author{
Chris Martiniakt
}

This Article examines sovereign immunity in the context of Hall $v$. Nevada, in which the Supreme Court of California held that the courts of California may assert jurisdiction over a suit by one of its citizens against the State of Nevada. The author finds the decision to be unsupported by the court's analysis, but contends that the result may be justified on other grounds and argues for the development of a federal law to govern such controversies.

It is inherent in the nature of sovereignty not to be amenable to the suit of an individual without its consent. This is the general sense, and the general practice of nnankind; and the exemption, as one of the attributes of sovereignty, is now enjoyed by the government of every State in the Union.

-Alexander Hamilton ${ }^{1}$

[Federal] jurisdiction in controversies between a state and citizens of another state is much objected, and perhaps without reason. It is not in the power of individuals to call any state into court.

-James Madison ${ }^{2}$

It is not rational to suppose that the sovereign power should be dragged before a court.

—John Marshall ${ }^{3}$

In Hall v. Nevada $a^{4}$ the California Supreme Court held that a superior court may, without the defendant's consent, take in personam jurisdiction over the State of Nevada. Because states are increasingly engaged in activities which carry them beyond their borders, the issue raised in Hall v. Nevada will arise at frequent intervals. Thus, the coin-

$\dagger$ B.S. 1969, University of Wisconsin, Madison; J.D. 1974, Boalt Hall School of Law.

1. THE Federalist No. 81, at 487 (Mentor ed. 1961) (A. Hamilton) (emphasis in original). The statement was in response to the notion that a citizen of one state could sue another state in a federal court.

2. J. Elliot, The Debates in the Several State Conventions on the AdopTION OF THE FEDERAL CONSTITUTION 533 (1881).

3. Id. at 555 .

4. 8 Cal. 3d 522, 503 P.2d 1363, 105 Cal. Rptr. 355 (1972). 
plex considerations and myriad strands of law involved in the suit merit close attention. The evolution of international law, the adaptation of that law to interstate disputes, and the constitutional considerations implicit in our federalism all bear upon the result reached in Hall. Although the result may be justifiable, the court failed to give adequate consideration to the underlying dilemmas.

\section{I}

Hall v. Nevada

Plaintiffs filed suit in San Francisco Superior Court to recover damages for personal injuries that resulted from a collision in California between their automobile and a car owned and operated by the University and State of Nevada.

The case came before the Supreme Court of California on plaintiff's appeal fron an order quashing service of summons upon the defendants. Service on the defendants had been made pursuant to California Vehicle Code section $17450,{ }^{5}$ which provides a method for service on nonresidents who lrave operated vehicles on California higlways, whose agents have done so, or who have consented to the use of their motor vehicles on California higlrways. With respect to accidents occurring in the state due to such use, the statutes provide for service on the Director of Motor Vehicles and notice of service to the nonresident by registered inail. ${ }^{6}$

The State of Nevada attacked service on grounds of sovereign immunity, rather than on the narrow grounds of statutory construction.

5. CAL. VeH. CODE $\S 17450$ (West 1971).

6. The relevant sections of the long-arm statute provide as follows:

$\$ 17451$. Service of process on nonresident

The acceptance by a nonresident of the rights and privileges conferred upon him by this code or any operation by himself or agent of a motor vehicle anywhere within this state, or in the event the nonresident is the owner of a motor vehicle then by the operation of the vehicle anywhere within this state by any person with his express or implied permission, is equivalent to an appointment by the nonresident of the director or his successor in office to be his true and lawful attorney upon whon may be served all lawful processes in any action or proceeding against the nonresident operator or nonresident owner growing out of any accident or collision resulting from the operation of any motor vehicle anywhere within this state by himself or agent, which appointment shall also be irrevocable and binding upon his executor or administrator.

$\S 17453$. Agreement on validity of process

The acceptance of rights and privileges under this code or any operation of a motor vehicle anywhere within this state as specified in Section 17451 shall be a signification of the irrevocable agreement of the nonresident, binding as well upon his executor or administrator, that process against him which is served in the manner provided in this article shall be of the same legal force and validity as if served on him personally in this state.

CAL. Veh. CODE $\$ \S 17451,17453$ (West 1971). 
No argument was made that the word "nonresident" was not intended to include states. The court refused to be intimidated by tradition, looking instead for sound, practical reasons why this action should be barred. ${ }^{7}$ Apparently finding no such reason, the court stated its holding as follows: "We have concluded that sister states who engage in activities within California are subject to our laws with respect to those activities and are subject to suit in California courts with respect to those activities."

Justice Peters, writing for a unaminous court, rested this holding on three lines of authority. First, he cited Parden v. Terminal Railway of the Alabama State Docks Department ${ }^{0}$ to support the proposition that waiver of immunity may be inferred fron use of the highway. Second, he cited several cases involving in rem or quasi in rent actions in a court of one state against a sister state or a city of a sister state. He concluded that "state sovereignty ends at the state boundary."10 Third, Justice Peters apphed the balancing approach entployed in cases upholding inodern long-arm jurisdictional statutes. ${ }^{11}$ The opinion also noted that California would not be immune froni suit on the cause of action presented and that sovereign immunity had recently been judicially eroded.

\section{II}

\section{THESIS}

\section{A. The Theory of the Court Examined}

No portion of the court's opinion withstands careful scrutiny. The court failed to confront cases and considerations contrary to its holding, and the cases it did cite can be easily and substantively distinguished.

Consider, for example, Parden v. Terminal Railway of the Alabama State Docks Department, ${ }^{12}$ in which the United States Supreme Court permitted a Georgia citizen to sue the State of Alabama in a federal court to recover under the Federal Employers Liability Act ${ }^{18}$

7. At oral argument before the California Supreme Court, Justice Tobriner asked counsel for Nevada why it followed that because states possessed sovereign immunity "in the days when knighthood was in flower" Nevada should now be exempted froin California's jurisdiction.

8. 8 Cal. 3d at 524, 503 P.2d at 1364, 105 Cal. Rptr. at 356.

9. 377 U.S. 184 (1964).

10. $8 \mathrm{Cal} .3 \mathrm{~d}$ at $525,503 \mathrm{P} .2 \mathrm{~d}$ at $1365,105 \mathrm{Cal}$. Rptr. at 357 . The principal cases on which the court relies are People ex rel. Hoagland v. Streeper, 12 Ill. 2d 204, 145 N.E.2d 625 (1957) and State v. Holcomb, 85 Kan. 178, 116 P. 251 (1911).

11. The court cites, among others, Hess v. Pawloski, 274 U.S. 352 (1927) and Buckeye Boiler Co. v. Superior Court, 71 Cal. 2d 893, 458 P.2d 57, 80 Cal. Rptr. 113 (1969).

12. 377 U.S. 184 (1964).

13. 45 U.S.C. $\$ \S 51-60(1970)$. 
(FELA) for injuries sustained while employed by Alabama's stateowned railway. The Court held that because it had engaged in interstate commerce, Alabama subjected itself to federal legislation-the FELA - and must be deemed to have waived its sovereign immunity. The revelance of this case to the situation presented by Hall is minimized, however, by the fact that the states stand in a different relationship to the federal government than they do sister states: the states surrendered power to the federal government when they joined the umion. ${ }^{14}$ Thus, not only was Alabama operating in an area of federal power, but it had previously agreed to grant the federal government the power to regulate the area in which it acted. ${ }^{15}$ Furthermore, the waiver theory of Parden, advanced by a badly divided Court, has since been restricted. ${ }^{16}$ But even in Parden the waiver was based on the states' knowledge that congressional exercise of delegated powers is the supreme law of the land and, if Congress so intends, it can exert legislative power over states as well as individuals. ${ }^{17}$ These considerations do not apply between Nevada and California. Nevada did not delegate power to California; California has no enforcement power over Nevada comparable to the authority of the federal government over the states. Thus, the decree in Parden is pursuant to an enforcement power possessed by the federal government, whereas jurisdiction over Nevada by California has to be justified in the absence of the power of enforcement. Moreover, since Hall is unprecedented, Nevada did not knowingly waive its immunity.

Similarly, those cases involving in rem or quasi in rem actions in a court of one state against a sister state ${ }^{18}$ or a city ${ }^{19}$ of a sister state, can be distinguished. Cities have often been held to be state-created cor-

14. See The Federaisst No. 32 (A. Hamilton); The Federalist Nos. 41-44 (J. Madison). Compare U.S. CoNsT. art. I, \$ 10 with U.S. CoNST. art. I, § 8.

15. 377 U.S. at 192.

16. Employees v. Missouri Dept. Pub. Health \& Welfare, 411 U.S. 279 (1973), seems to restrict the waiver theory to cases involving non-governmental acts. See Chamberlain, State Sovereign Immunity: No More King's X?, 52 TEx. L. Rev. 100 (1973).

17. The Court relied on United States v. California, 297 U.S. 175 (1936), which had applied federal statutes to state-owned railroads. In California the Court asserted: "The sovereign power of the states is necessarily diminished to the extent of the grants of power to the federal government in the Constitutiou." Id. at 184.

18. Georgia v. Chattanooga, 264 U.S. 472 (1924); People ex rel. Hoagland v. Streeper, 12 III. 2d 204, 145 N.E.2d 625 (1957); State v. Holcomb, 85 Kan. 178, 116 P. 251 (1911).

19. City of Cincinnati v. Commonwealth, 292 Ky. 597, 167 S.W.2d 709 (1942); State v. Hudson, 231 Minn. 127, 42 N.W.2d 546 (1950); State ex rel. Anderson v. Madison, 444 S.W.2d 443 (Mo. 1969). In the last inentioned case, the court actually dismissed the case for lack of subject matter jurisdiction. 
porate entities which do not share in the sovereignty of the state. ${ }^{20}$ More importantly, these cases do not involve in personam jurisdiction. ${ }^{21}$ In cases of this type the Supreme Court simply adhered to the long-estabhished principle that a state has in rem jurisdiction over property located within its borders, regardless of the identity of the owner. ${ }^{22}$ Moreover, in rein decrees clearly he within the power of a forum state to regulate the use or ownership of land or property within its borders and thus provide hittle authority for extension of personal jurisdiction to a sister state. Since in rem suits can be brought without in personam jurisdiction over the defendant, such suits provide questionable bases for acquisition of personal jurisdiction. ${ }^{23}$

At least one American case, Nathan v. Virginia, ${ }^{24}$ involves the question whether a state can be compelled to appear in a sister state court. The Pennsylvamia court held that sovereign immunity precluded jurisdiction. Other cases in which one court had voluntarily appeared in a sister state court held that sovereign immunity barred unconsented claims against then1. ${ }^{25}$ Some state courts have held that sovereign im-

20. It is an accepted rule that a municipality, although vested with certain sovereign powers when created by the state in which it is located, forfeits all claim to sovereignty with respect to property it has acquired or non-governmental activities it performs in another state. City of Cincinnati v. Commonwealth, $292 \mathrm{Ky} .597,167$ S.W.2d 709 (1942); Baker v. Kansas City, 118 Kan. 27, 233 P. 1012 (1925); State ex rel. Taggart v. Holcomb, 85 Kan. 178, 116 P. 251 (1911); National Shawmut Bank v. Waterville, 285 Mass. 252, 189 N.E. 92 (1934). These cases are distinguishable from Hall on the ground that they inerely deinonstrate the nature of municipal corporations, rather than confront the sovereiguty of states.

21. In People ex rel. Hoagland v. Streeper, 12 Ill. 2d 204, 145 N.E.2d 625 (1957), which involved au injunction against the conveyance of title from the city to the state, the court explicitly stated that it could obtain personal jurisdiction over the defendants. But the mjunction (which required personal jurisdiction) applied only to the city, not to the state (the potential transferee). The remaining issues in the suit involved in rem jurisdiction over the bridge approaclies on the Illinois side of the Mississippi. At another point in its opinion the Streeper court observed that where the property of anotler state is properly before the court, the court will proceed to disclarge its duty concerning the property but the state may not be compelled to come in as a party. Id. at 214 16,145 N.E.2d at $630-31$.

In Baker v. Kausas City, 118 Kan. 27, 233 P. 1012 (1925), the court held that it had in personam jurisdiction over a foreign municipality operating a water system in Kansas in a suit arising therein from conduct of the business, stating that the municipality does not share in sovereign immunity concerning non-governmental acts outside the state borders. It is not clear from the opinion whether the court regarded the sovereignty of the city as distinct from that of the state of Missouri.

22. Bank of the United States v. Planter's Bank, 22 U.S. (9 Wheat.) 904 (1824); Gcorgia v. Chattanooga, 264 U.S. 472 (1924).

23. See Florida State Hosp. v. Durham Iron Co., 194 Ga. 350, 21 S.E.2d 216 (1942), for a review of in rem and quasi in rein suits against states.

24. Nathan v. Virginia, 1 U.S. (1 Dall.) 77 (Court of Common Pleas, Philadelphia County 1781). This case is discussed at text accompanying note 42 infra.

25. Moore v. Tate, 87 Tenn. 725, 11 S.W. 935 (1889) (set-off against Alabama barred by sovereign immunity and Tennessee's own immnnity to set-off); Tappan v. 
mumity will prevent suit even where the basis of jurisdiction is quasi in rem. ${ }^{20}$ Hence, neither those cases on which the Hall court relied nor those they failed to mention lend much support to the proffered conclusion that "state sovereignty ends at the state boundary."27

The court also cited Hess v, Pawloski, ${ }^{28}$ in which the United States Supreme Court upleld the validity of a nonresident motorist statute similar to the one relied on in Hall. Pawloski may provide a model for the balancing of sovereign interests that the Hall case demands, ${ }^{29}$ but without some development it is not obvious that cases upholding jurisdiction over individuals or corporations are pertinent to whether a state court can obtain jurisdiction over a sovereign sister state. In fact, bald reliance on California's long-arm statutes begs the question whether Nevada's sovereignty immunizes it from California's legal authority.

\section{B. Drawing Lines: Sovereign Immunity}

Many of these flaws in the Hall court's rationale radiate from its failure to unravel the confusion surrounding the application of the sovereign immunity doctrine. One might first distinguislı suits brought against a sovereign im a subordinate forum (hereinafter "intrasovereign") from suits, like $\mathrm{Hall}$, brought against a sovereign in a foreign forum (hereinafter "intersovereign" suits). ${ }^{30}$ Yet in Hall the court cited witliout comment intrasovereign cases sucl1 as Muskopf v. Corning Hospital District ${ }^{31} \mathrm{im}$ which the California Suprene Court abrogated the immunity of a California mumcipality. Since a court cannot coerce the source of its authority, ${ }^{32}$ the California legislature could place suits like

Western \& Atlantic R.R., 71 Tenn. 106 (1879); Stockwell v. Bates, 10 Abb. Pr. (N.S.) 381 (Sup. Ct. 1871).

26. Florida State Hosp. v. Durham Iron Co., 194 Ga. 350, 21 S.E.2d 216 (1942); Van Horn v. Kittitas Co., 28 Misc. 333, 59 N.Y.S. 883, aff'd, 46 App. Div. 623, 61 N.Y.S. 1150 (1899).

27. 8 Cal. 3d at 525, 503 P.2d at 1365, 105 Cal. Rptr. at 357.

28. 274 U.S. 352 (1927).

29. See the discussion at text accompanying notes 89-93 infra.

30. For example, a suit against the United States brought in a federal court or a suit against a state brought in a court of that state represent intrasovereign conflicts. In such cases local law determines the immnnity enjoyed by the domestic sovereign in its own courts.

Examples of intersovereign conflicts include a suit in a court of one nation against a foreign nation (international law) or a suit in a conrt of one state against a foreign state, as was the case in Hall. Though the political ramifications of international disputes differ from those of interstate conflicts, the thcoretical basis is very similar.

31. 55 Cal. 2d 211, 359 P.2d 457, 11 Cal.Rptr. 89 (1961).

32. As Justice Holmes put it:

Some doubts have been expressed as to the source of the immimity of a sovereign power from suit withont its own permission, but the answer has been public property since before the days of Hobbes. Leviathan, Chap. 26,2. A sovereign is exempt from suit, not because of any formal conception or obso- 
Muskopf beyond the authority of California courts. In suits brought in a foreign court, the forum is not subject to the authority of the defendant sovereign; therefore, problems arise which are different from those a court confronts in deciding whether to waive its own state's sovereign immunity. International imcidents may occur; or, by entertaining the suit, the court may interfere with those branches of government whose sphere is international relations. In the interstate context notions of comity and federalisin must be considered.

Most courts have referred to sovereign immunity as a jurisdictional immunity. ${ }^{33}$ But "jurisdiction" has more than one meaning. In the intersovereign context, as in Hall, sovereign immurity has often meant immunity froin process. Thus, in the clearest case of "jurisdictional" immunity, the sovereign is immune froin the personal jurisdiction of the court. The manner in which the issue arose in Hall suggests that the court conceived of sovereign immunity in this sense, ${ }^{34}$ apparently expanding the in personam jurisdiction of state courts.

Other courts have treated sovereign immunity as immunity from the application of the laws of the forum. ${ }^{36}$ Immunity from liability in the intersovereign context, however, must be distinguished from immunity from hability in the intrasovereign (or domestic) context. Intersovereign immunity from hability follows from the assumption that the laws of one forum cannot bind a sovereign, while intrasovereign immu-

lete theory, but on the logical and practical ground that there can be no legal right as against the authority that makes the law on which the right depends.

Kowananakoa v. Polybank, 205 U.S. 349, 353 (1907).

33. E.g., Puerto Rico v. Rosaly y Castillo, 227 U.S. 270 (1913); Cunningham v. Macon \& B.R.R., 109 U.S. 446 (1883); Nathan v. Virginia, 1 U.S. (1 Dall.) 77 (Court of Common Pleas, Philadelphia County 1781); Puente v. Spanish Nat. State, 116 F.2d 43 (2d Cir. 1940); Nankivel v. Omsk All-Russian Government, 237 N.Y. 150, 142 N.E. 569 (1923); Mason v. International Ry. of Canada, 197 Mass. 349, 83 N.E. 876 (1908). See generally Comment, The Jurisdictional Immunity of Foreign Sovereigns, 63 YALE L.J. 1148 (1954); Lauterpacht, The Problem of Jurisdictional Immunities of Foreign States, 28 BRIT. Y.B. INr'L L. 220 (1951) [hereinafter cited as Lauterpaclit]; Lalive, L'imunite de Jurisdiction des Etas et des Organizations Internationaux, 84 RECEUIL DES Cours 205 (The Hague Acad. of Int. Law 1953).

34. The case was an appeal from an order quashing service of process on defendants.

35. The following cases treat sovereign immunity as an exemption from legal liabihty: Moore v. Tate, 87 Tenn. 725, 11 S.W. 935 (1889); Tappan v. Western \& Atlantic R.R., 71 Tenn. 106 (1879); Florida State Hosp. v. Durham Iron Co., 194 Ga. 350, 21 S.E.2d 216 (1942).

Other cases have held that sovereign immunity operates even to insulate property of the sovereign from in rem actions. E.g., Exchange v. McFadden, 11 U.S. (7 Cranch) 116 (1812); Moitez v. The South Carolina, 17 Fed. Cas. 594 (No. 9,697) (Admiralty C. Penn. 1781); Briggs v. Light Boat, 93 Mass. (11 Allen) 157 (1865); Van Horn v. Kittitas County, 28 Misc. 333,59 N.Y.S. 883, aff d, 46 App. Div. 623, 61 N.Y.S. 1150 (1899). 
nity from liability provides that the law of the forum exempts the domestic sovereign from liability under a given statute. ${ }^{38}$

Another consideration is justiciability, ${ }^{87}$ which focuses, in part, on the competence of the court to entertain a suit with possible diplomatic repercussions. The court may perceive its jurisdiction over such suits as being implicitly restricted because of possible embarassment to or interference with other branches of government. Thus, the political question doctrine might explain the dismissal of in rein and quasi in rem suits against a foreign sovereign. ${ }^{88}$

Execution of the judgment presents another problem. In international law, judgments obtained against a sovereign, even if by consent to suit, may not be executed against any of the sovereign's property without its consent. ${ }^{39}$ The Hall court, however, did not discuss whether one of the United States may cause the execution of judgment against another state even though the applicability of Parden depends on this ability. ${ }^{40}$

Parden and Hall also reveal the unique aspects of sovereign immunity in the interstate context. The relation of California to Nevada does not parallel that of one nation to another. Nor does a state occupy a "subordinate" position to the federal government in the saine sense that a county or city does to its encompassing state. A reasoned approach to the problem presented by Hall therefore requires an analysis of the constitutional framework of federalism.

36. See, e.g., Nev. Rev. STAT. $\S \S 41.032,41.033$ (1973).

37. See P. Bator, P. Mishkin, D. Shapiro \& H. Wechsler, Hart and WechsIER's The Federal Courts aNd The Federal System 64-241 (2d ed. 1973). The justiciability doctrine includes notions of ripeness, mootness, standing, and political question.

38. See generally C. Warren, The Supreme Court and Sovereign States 5360 (1924) [hereinafter cited as WARREN]; Brown, The Classification of Justiciable Disputes, 16 AM. J. INT'L L. 254 (1922).

39. For American law on this subject see Myers, Contemporary Practice of the United States Relating to International Law, 54 AM. J. INT'L L. 632, 643 (1960). See also Berlonti Coustr. Co. v. Republic of China, 145 So. $2 \mathrm{~d} 256$ (Fla. Dist. Ct. App. 1962); United States v. Harris \& Co. Advertising, Inc., 149 So.2d 384 (Fla. Dist. Ct. App. 1963); State ex rel. Nat'1 Institute of Agrarian Reform v. Diekle, 137 So.2d 581 (Fla. Dist. Ct. App. 1962). That execution immunity is the general rule in international law is acknowledged and strongly criticized by many commentators. E.g., Fensterwald, Sovereign Immunity and Soviet State Trading, 63 HARV. L. Rev. 614, 626 (1950); Lauterpraclit, The Problem of Jurisdictional Immunities of Foreign States, 28 BrIT. Y.B. INT'L L. 220, 222 (1951); Timberg, Sovereign Immunity, State Trading, Socialism and Self-Deception, 56 Nw. U.L. Rev. 109 (1961). Courts in some countries, including France, Belgium, Czecloslovakia, Switzerland, Egypt, Italy, Holland, Greece, and Russia, lave denied claims of execution immumity by defendant sovereigns. W. Bishop, InTERnational LaW 580-81 (2d ed. 1962); Note, Doing Business with State Agencies, 1965 U. ILL. L. ForUM. 536; Timberg, supra at 120.

40. See the discussion at text accompanying notes 12-17 supra. 


\section{Federalism Considered}

One can argue that the Constitution implicitly assumes the notion of interstate sovereign immunity as a premise integral to the whole federal scheme. ${ }^{41}$ In Nathan $v$. Virginia, ${ }^{41}$ decided shortly before the Constitutional Convention, personal property belonging to Virgima was attached by the sheriff in Philadelphia. This seriously threatened already strained interstate relations. The Virginia delegates to the Confederation Congress applied to the Supreme Executive Council of Pennsylvauna. Apparently adopting the accepted doctrine of the day, the Council quashed the attachment and held that Virgmia possessed immunity from suit in the courts of sister states. ${ }^{43}$ The case must have been well known, ${ }^{44}$ both to the delegates to the Constitutional Convention and to the state legislatures, since these legislative bodies were concerned with the relationship of the states to the proposed federal government. Thus, its holding may well have played a tacit part in the construction and acceptance of the federal constitutional scheme.

Other evidence of the status of the concept of sovereign immunity of the states in the eyes of the Framers and ratifiers emerges from the

41. Compare the right to travel within the United States which, although not specifically guaranteed in the constitution, the Supreme Court has found implicitly guaranteed:

Although the Articles of Confederation provided that 'the people of each State shall have free ingress and regress to and from any other State,' that right finds no explicit mention in the Constitution. The reason, it has been suggested, is that a right so elementary was conceived from the beginning to be a necessary concomitant of the stronger Union the Constitution created.

United States v. Guest, 383 U.S. 745, 758 (1966) (citations omitted). In Crandall v. Nevada, 73 U.S. (6 Wall.) 35 (1867), Mr. Justice Miller writing for the Court stated that the right to move freely throughout the nation was a right of national citizenship. That the right was implied did not make it any the less "guaranteed" by the Constitution. See also Edwards v. California, 314 U.S. 160 (1941); Twining v. New Jersey, 211 U.S. 78, 97 (1908); Williams v. Fears, 179 U.S. 270 (1900); Corfield v. Corycll, 6 F. Cas. 546 (No. 3,230) (C.C.E.D. Pa. 1825).

42. 1 U.S. (1 Dall.) 77 (Court of Common Pleas, Philadelphia County 1781).

43. Although the court did not deliver an opinion it upheld the position of the Attorney General for Virginia who argued that "thougl the several states which form our federal republic, had, by the confederation, ceded many of the prerogatives of sovereignty to the Umited States, yet these voluntary engagements did not injure thcir independence on each other; but that each was a sovereign 'with every power, jurisdiction, and right, not expressly given up' [and] . . . every kind of process issued against a sovereign, is in violation of the laws of nations; and is, in itself, null and void." 1 U.S. (1 Dall.) at 78. A footnote to the decree of the court reads: "Stockwell v. Bates, 10 Abb.Pr.(NS) 381. The true ground of this decision is, that a sovereign state is not suable in the inunicipal courts of another jurisdiction, and a foreign attachment is but a mode of compelling an appearance. Whilst the states have surrendered certain powers to the general government, they have not divested themselves of the attribute of state sovereignty." Id. at 80-81.

44. See, e.g., C. JACobs, The Eleventh AMEndment and Sovereion Immunity 12-13 (1972) [hereinafter cited as JACOBS]. 
treatment of that principle as applied to issues regarding the jurisdiction of the federal courts. One commentator has argued that at the time of ratification, no "understanding" existed as to the question whether federal jurisdiction extended to suits by individuals against the states. $^{45}$ Federalists such as Hamilton and Madison ${ }^{46}$ denied, in expositions of the Constitution upon which the states were to base their decisions, that states would be amenable to suit. ${ }^{47}$ On the other hand, others, mostly opponents of ratification, asserted that article III $^{48}$ would make states amenable to suit in federal courts. ${ }^{49}$ Because of this uncertainty, to ensure that article III would not subject states to federal court jurisdiction in suits brought by individuals, the conventions of at least four states ${ }^{50}$ recommended delimiting or explanatory statements. Among these states were New York and Virginia, whose adoption of the Constitution was considered essential to the success of the Union. ${ }^{51}$

Events leading up to the passage of the eleventh amendment ${ }^{52}$ confirm the general understanding of the states that they were to remain immune from suit. Immediately after the establishment of the federal courts, several individuals brought suits before the Supreme Court $^{53}$ to recover debts that states had incurred during the war or the financially unstable period following the war. In Chisholm v. Geor-

45. JACOBS 40 .

46. See text accompanying notes 1-3 supra.

47. Jacobs discounts these statements as political concessions. JACOBS 12.

48. Section 2, paragraph 1 reads: "The judicial power shall extend to . . . controversies between two or more states; -between a State and Citizens of another State; -between Citizens of different States; . . . and between a State, of the Citizens thereof, and foreign States, Citizens, or Subjects." U.S. CoNST. art. III.

49. JACOBS 28-40.

50. Virginia, New York, North Carolina, and Rhode Island. JACOBS 35-39.

51. Rossiter, Introduction to The Federalist PAPERS (Mentor ed. 1961).

52. The eleventh amendment states:

The judicial power of the United States shall not be construed to extend to any suit in law or equity, commenced or prosecuted against oue of the United States by citizens of another State, or by citizens or subjects of any foreign State.

U.S. CONST. amend. XI.

53. Chisholm v. Georgia, 2 U.S. (2 Dall.) 419 (1793); Oswald v. New York, 2 U.S. (2 Dall.) 401 (1792); Vanstophorst v. Maryland, 2 U.S. (2 Dall.) 401 (1791). The Vanstophorst case was the first case docketed before the Supreme Court. Other suits were brought by individuals against states which raised questions arising under the Constitution, laws and treaties of the United States. E.g., Gayson v. Virginia, 3 U.S. (3 Dall.) 320 (1796); Vassal v. Massacliusetts, unreported U.S.S.C. (1793), Minutes of the Supreme Court, August 6,1793. The cases which liad not already been settled by the time the eleventh amendment was ratified were dismissed at that time. However, they had some lasting influence on the law, for in interstate cases before the Supreme Court on original jurisdiction the Court relied on a rule laid down in these early suits that the Court lad power to proceed ex parte if a refractory state refused to appear when duly summoned. 
gia ${ }^{54}$ the Supreme Court asserted jurisdiction under article III and entered judgment against Georgia. The states were aghast at this result: Georgia's lower house passed a bill which would have made it a capital offense to enforce Chisholm's judgment. ${ }^{\text {t5 }}$ Within three months after the Third Congress convened, the eleventh amendment was proposed for ratification by the states. This amendment received almost universal, bipartisan support ${ }^{56}$ and ratified by the requisite 12 of the then 15 states within 11 months after its proposal by Congress. This swift and decisive reaction by the states suggests that they perceived Chisholm as an unexpected expansion of federal power. ${ }^{57}$ Passage of the eleventh amendment has been viewed as restoring the origimal understanding of the states that without their consent they could not be sued in federal courts. ${ }^{58}$ This reacling of the passage of the eleventh amendment, coupled with the proposition of Nathan $v$. Virginia - that at the time of ratification, a state was not amendable to suit in courts of the sister states ${ }^{50}$-leads to the conclusion that Hall was wrongly decided.

\section{III}

\section{ANTITHESIS}

\section{A. A Theory Proposed}

Nathan $v$. Virginia reflects the international law notions of the 18th century under which a foreign sovereign could not be sued without its consent. $^{60}$ This doctrine no longer governs international disputes.

54. Chisholm v. Georgia, 2 U.S. (2 Dall.) 419 (1793).

55. The Augusta Chronicle, November 23, 1793, reporting the action of Novcmber 19. The text of the bill is reprinted in JACOBS 56 .

56. J ACOBS 71 .

57. Jacobs disputes this conclusion, based mainly on his conviction that there had been no prior understanding as to the extent of federal judicial power. He does not take the swift passage of the eleventh amendment as evidence of that understanding, but neither does he satisfactorily explain why the amendment otherwise received universal endorsement even by the Federalists after the Constitution had been adopted so that there was no longer a political motive to appease the opposition. The fact that the Federalists could be consoled by the fact that the states had largely repaid their debts does not explain their advocacy of the amendment.

58. Another explanation for this reaction, which is not inconsistent, is that the states were still heavily in debt. Jacobs disputes that debt avoidance was a motivating factor since the states later paid most of the debts. Elsewhere, however, he considers the fact that suits were pending against several states an important reason for the swift passage of the eleventh amendinent. Compare JACOBS 69-70, with JACOBS 57. About 12 states defaulted on some of their obligations, with Virginia, Louisiana, North Carolina, and South Carolina causing the most litigation. ScotT, THE REPudiation of State DebTs (1893).

59. See text accompanying notes $42-44$ supra.

60. Comment, The Jurisdictional Immunity of Foreign Sovereigns, 63 YALE L.J. 
It need not govern interstate disputes since the broad principles of constitutional interpretation permit the developinent of interstate sovereign immunity along the lines international law has taken.

The revolution in international law began in 1886 with the introduction of the theory of restrictive sovereign immunity. ${ }^{61}$ Under the new doctrine, immunity only protected a foreign sovereign on causes of action which arose out of activities performed by the sovereign in a governmental capacity (jure imperii). All other acts (jure gestionis), such as commercial transactions, exposed the sovereign to suit like any other nonsovereign entity. ${ }^{62}$ This natural distinction has been used in other areas of the law, such as in determining the liability of Inunicipal corporations, and in many state statutes defining the hability of the doinestic sovereign.

The Court of Cassation of Naples first enunciated the principles of the restrictive theory in a judgment of March 27, 1886. ${ }^{63}$ The decision was followed a few months later by the Court of Cassation of Florence and in 1893 by the Court of Cassation of Rome, ${ }^{64}$ thus firmly establishing the principle in Italy before the turn of the century. In 1903 the Belgian Court of Cassation followed suit, saying "the immunity of foreign states from the jurisdiction of foreign courts can be invoked only where their sovereignty is affected thereby." 65 The court concluded that when the state possesses property, concludes agreements, constitutes itself creditor and debtor, or engages in coinmerce, it acts not as a political entity but rather as a private individual.

From there the adoption of restrictive immunity spread to numerous countries of the world. By 1951 Lauterspacht could state that absolute immunity was no longer a principle of international law. ${ }^{86}$ The restrictive theory gained its greatest impetus from two intertwined

1148,1150 (1954). For a discussion of the doctrine's development, see Riesenfeld, Sovereign Immunity of Foreign Vessels in Anglo-American Law: the Evolution of a Legal Doctrine, 25 MINn. L. REv. 1 (1940).

61. Mirabelli v. Winspear [1886], 38 Giur. Ital. I 228 (Corte di Cassazione).

62. Id. Just seven years before restrictive immunity was introduced to international law the court in Tappan v. Western \& Atlantic R.R., 71 Tenn. 106 (1879), said it did not appreciate the "ingenious" argument presented by plaintiff that the State of Georgia was engaged in non-governmental activities and thus should not be given the cloak of immunity from suits arising out of those activities. According to the court, a sovereign wears this mantle regardless of its activities.

63. Mirabelli v. Winspear [1886], 38 Giur. Ital. I 228 (Corte di Cassazione).

64. Vigliani v. Martucci [1886], 38 Giur. Ital. I 486 (Corte di Cassazione); Tondi v. Caselli [1893], 45 Giur. Ital. I 1213 (Corte di Cassazione).

65. Societe Anonyme des Chemins de Fer Liegeois-Luxemburgeois v. The Netherlands 1903, Clunet, 1904, 417.

66. Lauterpacht, supra note 33. 
developinents. ${ }^{67}$ First, rather than being embodied in jealous potentates, sovereigns were more often somewhat reasonable governments, many of which had begnn to admit liability at home through various tort claims acts. Second, these governments imcreasingly engaged im normal business enterprises as well as in "sovereign" activities. It was not clear why a trade dispute or tort case should differ merely because the defendant commercial enterprise was government operated.

In addition to these major thrusts, other developments facilitated the move toward the restrictive theory. The view of sovereign immumity as a "superlaw" principle flowing from the equality of nations was effectively challenged. The "equality of nations" principle no more supports absolute intersovereign immumity than other formulations:

[N]o legitimate claim of sovereignty is violated if the courts of a state assume jurisdiction over a foreign state with regard to contracts concluded or torts committed in the territory of the state assuming jurisdiction. On the contrary, the sovereignty, the independence, and the equahity of the latter are denied if the foreign state clains as a matter of right-as a matter of international law-to be above the law of the state within the territory of which it has engaged in legal transactions or committed acts entailing legal consequences according to the law of that state. The absence of any denial of independence or equality appears even more clearly when the state exercising jurisdiction over a foreign state submits itself, within the same sphere, to the full operation of its own law without claiming any privileged status or immunity. ${ }^{68}$

In addition, jurisdiction became a matter of fairness rather than remaining strictly tied to the concept of territorial power. Although the possibility that decrees may be unenforceable continued to be a problem, ${ }^{69}$ the feeling grew that a court's decree, if fairly wrought, carries some value of its own, if only as a first step toward redress through diplomatic channels. ${ }^{70}$ As the legitimacy of such suits increases in the eyes of the courts, so will the moral force and persuasiveness of the

67. See Bunden, Sovereign Immunity of Government-Owned Corporations and Ships, 39 CORNeLL L.Q. 425, 427-31 (1954).

68. Lauterpacht 229.

69. In Puente v. Spanish Nat. State, 116 F.2d 43 (2d Cir. 1940), the court held that in an action brought against a sovereign directly there is no vestige of jurisdiction, concluding: "This is a reasonable and rational view; no court should be expected to stultify itself by entering a judgment which it knows cannot be enforced against protest." Id. at 45 .

70. The securing of a judgment against a foreign government may serve as an inducement to that government to settle with the judgment holder. For example, although execution against the Swedish government was denied in Dexter \& Carpenter, Inc. v. Kunglig Jarnvagsstyrelseu, 43 F.2d 705 (2d Cir. 1930), cert. denied, 282 U.S. 896 (1931), the government eventually paid $\$ 150,000$ in settlement of the $\$ 411,203.72$ judgment against it, 2 HACKWORTH, DIGEST OF INTERNATIONAL LAW 480 (1941). 
naked decree. Whatever absolute sovereign immunity renuains has been retained largely because of judicial inertia and "to avoid possible embarrassment to those responsible for the conduct of the nation's foreign relations." 71

The restrictive theory did not reach the United States officially until 1952, at which time the publication of the Tate letter ${ }^{72}$ announced that the United States Department of State-to whose policies our courts have considered themselves bound ${ }^{73}$-officially adopted the restrictive theory. As late as it was, this move nuay have been a mere cold war tactic. ${ }^{74}$

Only in 1964 did a federal court actually take jurisdiction over a foreign sovereign on the basis of the restrictive theory of immunity. The case, Victoria Transport Inc. v. Comisaria General, ${ }^{75}$ had been anticipated by several state courts which had already acted on the new theory by assuming jurisdiction over foreign sovereigns. ${ }^{76}$ Several state and federal courts have done so since. ${ }^{77}$ Thus, it appears that the re-

71. Victory Transport Inc. v. Comisaria General, 336 F.2d 354, 357 (2d Cir. 1964), cert. denied, 381 U.S. 934 (1965).

72. 26 DEP'T STATE BULL. 984 (1952).

73. Ex parte Peru, 318 U.S. 578, 586-88 (1943).

74. The Tate letter states near the end:

It is thus evident that with the possible exception of the United Kingdom little support has been found except on the part of the Soviet Union and its satellites for contmued full acceptance of the absolute theory of sovereign immunity. ... The reasons which obviously motivate state trading countries in adhering to the theory with perhaps increasing rigidity are most persuasive that the United States should change its policy.

26 Dep't STATR Bull. 984, 985 (1952).

75. 336 F.2d 354 (2d Cir. 1964).

76. Harris \& Co. Advertising, Inc. v. Republic of Cuba, 127 So. 2d 687 (Dist. Ct. App. Fla. 1961); Et Ve Balik Kukumu v. B.N.S. Int'l Sales Corp., 17 App. Div. 2d 927, 233 N.Y.S.2d 1013 (1962), aff's mem., 25 Misc. 2d 299, 204 N.Y.S.2d 971 (Sup. Ct. 1960); Pacific Molasses Co. v. Comite De Ventas De Mieles, 30 Misc. 2d 656, 219 N.Y.S.2d 1018 (Sup. Ct. 1961); Three Stars Trading Co. v. Republic of Cuba, 32 Misc. 2d 4, 222 N.Y.S.2d 675 (Sup. Ct. 1961).

77. E.g., Petrol Shipping Corp. v. Kingdom of Greece, Ministry of Coinmerce, 360 F.2d 103 (2d Cir. 1966); Anaconda Co. v. Corporacion Del Cobre, 55 F.R.D. 16 (S.D.N.Y., 1972); Premier Steamship Corp. v. Embassy of Algeria, 336 F. Supp. 507 (S.D.N.Y. 1971); Amkor Corp. v. Bank of Korea, 298 F. Supp. 143 (S.D.N.Y. 1969); Pan American Tankers Corp. v. Republic of Vietnam, 296 F. Supp. 361 (S.D.N.Y. 1969); Ocean Transport Co. v. Government of Republic of Ivory Coast, 269 F. Supp. 703 (E.D. La. 1967); French v. Banco Nacional de Cuba, 23 N.Y.2d 46, 295 N.Y.S.2d 433 (1968).

In American Hawaiian Ventures, Inc. v. M.V.J. Latuharhary, 257 F. Supp. 622 (D.N.J. 1966), the court attempts to limit the holding of Victory Transport to suits wherein the sovereign had consented to suit by contract as it had in Victory Transport, as well as in Anaconda, Premier Steamship, Pan American, and Petrol Shipping. But in French the state court took jurisdiction and denied immunity despite the lack of any previous agreement or consent by Cuba. 
strictive theory is finally on its way to becoming entrenched in American law. ${ }^{78}$

\section{B. Drawing Lines: Restrictive Sovereign Immunity}

The theory poses one major problem: how will immune acts be distinguished from unprotected ones? This dichotomy of governmental and non-governmental acts corresponds to one way of balancing noninterference with affairs of state against the imjustice of denying claims for recovery in essentially commercial areas. Because the distinction rests on political considerations, judicial administration in a legally consistent manner presents some problems. Attempts to place the distinction on any analytical foundation have met with singular lack of success and the case law is at hopeless odds. ${ }^{79}$

78. As early as 1918 the State Department had expressed its view that foreign sovereigns were not entitled to immuuity while engaging in commercial pursuits. Letter from Secretary Lansing to the Attorney General, November 8, 1918, in 2 HACKWORTH, DigesT OF INTERNATIONAL LAW 429 (1941). In 1921 the State Department "suggested" that no immunity be recognized in Berizzi Bros. v. S.S. Pesaro, 271 U.S. 562 (1926), due to the commercial nature of the transaction. "Vessels owned by a state and engaged in commerce . . . are subject to the local jurisdiction to the same extent as other merchant vessels." 2 HACKWORTH, supra at 437 (1941). When the court nonetheless granted immunity based on the absolute theory, the State Department abandoned its restrictive policy and reverted to suggestions based on the absolute theory. Later in a dictum in Mexico v. Hoffman, 324 U.S. 30 (1945), the Court invited the State Department to ignore Pesaro and indicated that it might be willing to go along with a restrictive theory. "It is therefore not for the courts . . to allow an immunity on new grounds which the government has not seen fit to recognize." 324 U.S. at 35.

In fact, there are passages in Exchange v. McFaddon, 11 U.S. (7 Cranch) 116 (1812), which foreshadow the restrictive theory:

Without indicating any opinion on this question, it may safely be affirmed, that there is a inanifest distinction between the private property of the person who happens to be a prince, and that military force which supports the sovereign power, and maintains the dignity and the independence of a nation. A prince, by acquiring private property in a foreign countsy, may possibly be considered as subjecting that property to the territorial jurisdiction; he may be considered as so far laying down the prince, and assuming the character of a private individual; but this he cannot be presumed to do, with respect to any portion of that armed force, which upholds his crown, and the nation he is intrusted to govern.

11 U.S. (7 Cranch) at 144. Umited States Attorney Dallas, who argued that immunity should be recognized before the Supreme Court, admitted that our courts could not deny "liability for his private debts and contracts. ..." "So, if a sovereign descend from the throne and become a merchant, he submits to the laws of the country. If he contract private debts, his private funds are liable. So, if he charter a vessel, the cargo is hable for the freight." Id. at 123 .

79. Transactions connected with a tobacco monopoly were held by a $\mathrm{Ru}$ manian court to be jure gestionis and as such subject to its jurisdiction. An American court came to an opposite conclusion. While the activities of a state calculated to promote immigration were held by a Belgian court to be an act jure imperii, an Italian court held otherwise.

Italian courts have held that a contract made by a foreign state for the purchase of shoes for its army was an act of a private-law nature and therefore 
Lauterpacht has pointed out that all acts by sovereigns are sovereign acts. ${ }^{80}$ Different nations have regarded different state functions as sacrosanct. Some courts attempting to classify activities have looked to the "nature" of the activity, others have looked to the "purpose."81 The "nature" test might, for example, lead a court to conclude that a purchase is in the nature of a private act. The "purpose" test might lead a court to grant immunity if the goods purchased were military supplies. Thus, much depends on how one formulates the characterization of the activity in question: for example, buying shoes, or equipping an army; driving in city traffic, or picking up embassy mail.

One suggestion resolves some of the difficulties by abandoning the attempt to arrive at a general systematic definition of the distinction. Instead, one of two things might be done: (1) List those activities which will be protected from suit; ${ }^{82}$ or (2) use an assimilation approach. The latter approach puts the foreign sovereign in the shoes of the domestic sovereign for the purpose of suit. ${ }^{83}$ Its adoption has been suggested by international scholars as the best solution in that context. ${ }^{84}$ This suggestion has some case law support, ${ }^{85}$ as well as several advan-

outside the principle of immunity. A court in the United States decided that the same transaction constituted for the state 'the highest sovereign function of protecting itself against the enemies.' The same view was expressed nearly a century before in a leading decision of the French Court of Cassation in the matter of the purchase of shoes for the Spanish army.

Lauterpacht, 223 (footnotes omitted).

80. Lauterpacht 224. See also The Pesaro, 277 F. 473, 482 (S.D.N.Y. 1921).

81. See generally Lauterpacht 223; Bunden, Sovereign Immunity of GovernmentOwned Corporations and Ships, 39 CORNelL L.Q. 425, 434-36 (1954).

82. Such a list was suggested in Victoria Transport, Inc. v. Comnisaria General, 336 F.2d 354 (2d Cir. 1964), and several writers have proposed lists. See Lauterpacht 237-39.

83. It should be pointed out that many states still adhere to some form of governmental/non-governmental activity distinction in their local immunity laws. Thus, the restrictive theory would, in effect, reappear.

84. Lauterpacht 226; Comment, The Jurisdictional Immunity of Foreign Sovereigns, 63 YALE L.J. 1148, 1165 (1954). This approach comes full circle historically, since foreign sovereign immunity was rooted in the concept of domestic immunity.

85. In international law: Long v. The Tampico, 16 Fed. 491, 495 (S.D.N.Y. 1883). A more recent case stated: "In the absence of statute or treaty, no sound primciple of law or of international comity requires that the courts of this country treat a foreign government more favorably as to sovereign iminunity than our own government is treated by the courts." The Beaton Park, 65 F. Supp. 211, 212 (W.D. Wash. 1946). states:

In interstate law: Moore v. Tate, 11 S.W. 935 (Tenn. 1889), in which the court

[I]t is sufficient to say that it is without exception, so far as we know, that the courts of one state, in dealing with a sister state, extend to it all the privileges enjoyed by the state in which the court is held, unless there be some imperative rule of law to the contrary; so that in the consideration of the case at bar we have treated, and propose to treat, the question as though it concerned the state of Tennessee.

Id. at 937.

[W]ithout further discussion, we hold that an independent claim cannot be set off against a demand of the state, defensively or otherwise, without the 
tages. It clearly defines what is not protected activity, giving warning to potential defendant states. It is comitous since it provides the same protection to both foreign and forum states; ${ }^{80}$ and it is no less fair to the domestic citizens than their own laws are.

A third alternative treats the foreign sovereign as it would be treated in its own country. ${ }^{87}$ This approach shows more deference than the assimilation approach and thus would be less apt to cause interstate enmity. Several reasons make such treatment undesirable. First, the forum courts can apply their own law more easily than they can apply that of another state. Second, applying the policies chosen by the people of the foreign state disadvantages the plaintiff injured in the forum state, unless, of course, those policies are more liberal. This possibility could lead to a hybrid approach whicls would allow suit if the laws of one or the other state would permit it. Though little precedent can be found for such an approach, sound policy arguments support the idea. The performance of the courts in cases involving conflicting laws indicates that once doctrines of sovereign immunity have been sufficiently eroded, courts will use whatever reasoming best protects the in-state plaintiff. ${ }^{88}$

Hall apparently stated a less restrictive rule: respect for sovereignty can be preserved most evenhandedly where the only "restriction" is that the suit arise from acts occurring "within" the forum state. The Hall court started with the assumption that states generally enjoy immumity from unconsented suit, but that where a conflict of sovereign integrity exists the solution which damages sovereignty the least and works the greatest justice will be cliosen ${ }^{89}$ For example, Hess v. Pawlosk $i,{ }^{00}$ cited by the court in Hall, can be seen as a case in which the

affirmative consent of the state, and that the courts of this state will apply to a sister state suing here the same rule in this respect that is applicable to our own state when a plaintiff.

Id. at 939. See also Florida State Hosp. v. Durham Iron Co., 194 Ga. 350, 21 S.E.2d 216,219 (1942). Both these state cases, however, mention the idea in a context where local government enjoys immunity.

86. Applying the assimilation approach to Hall v. Nevada, one can ignore the question whether the educational activities being performed by the University of Nevada were governmental or not, since California abrogated sovereign immunity in Muskopf v. Corning Hospital Dist., 55 Cal. 2d 211, 359 P.2d 457, 11 Cal. Rptr. 89 (1961).

87. This view was considered and rejected by the court in Dexter S. Carpenter v. Kunglig, 43 F.2d 704, 710 (2d Cir. 1930).

88. See R. Cramton \& D. Currie, Conflict of Laws 56-147 (1968).

89. This is referred to in the principle enunciated by the court in Hall: "When the sister state enters into activities in this state, it is not exercising sovereign power over the citizens of this state and is not entitled to the benefits of the sovereign immunity doctrine as to those activities unless this state has conferred immunity by law or as a matter of comity." $8 \mathrm{Cal}$. 3d at 524, $503 \mathrm{P} .2 \mathrm{~d}$ at 1364, $105 \mathrm{Cal}$. Rptr. at 356.

90. 274 U.S. 352 (1927). 
Court felt that the Massachusetts statute expanding state jurisdiction into those states where a potential defendant resides ${ }^{91}$ did less damage than the damage which would be suffered by Massachusetts' sovereignty without such a statute. ${ }^{92}$

According to this reasoning the defendant state's sovereignty should give way when and only when it seriously conflicts with the sovereignty of the forum. Thus, this foundation for the overriding of sovereign immumity carries with it an inherent limitation. For exemple, if Nevada owned property in Oregon, and Hall, after obtaining a judgment against Nevada, wished to satisfy his judgment out of that property, he would have to bring an action for enforcement against Nevada in Oregon. But if Nevada asserted its sovereign immunity it would be very difficult to argue that this immunity must give way because it seriously conflicts with Oregon's sovereignty. ${ }^{93}$

There are other implications of the Hall approach. For example, a state legislature may explicitly extend immunity to sister states engaging in certain activities in return for similar treatment, or perhaps with an eye to inviting interstate ventures. This, however, might require negotiation of a compact approved by Congress declaring inutual submission to jurisdiction under agreed circunistances. In fact the provision in the Constitution for interstate compacts may be the only way states can bind one another. ${ }^{94}$ Significantly, the requirement that interstate compacts be approved by Congress indicates that such interstate actions are matters of federal interest to be controlled by Congress.

In the absence of compacts, linitations on the assertion of sovereign immunity may flow from federal or constitutional considerations and therefore bind the states, as the law of sister states cannot. In international law each nation decides the reach of its own law. No superauthority prevents an expansive view, or requires any nation to recog-

91. The Court was still influenced by the territorial concept of jurisdiction which was an adjunct of territorial sovereignty:

The process of a court of one state cannot run into another and summon a party there domiciled to respond to proceedings against him. Notice sent outside the state to a nonresident is unavailing to give jurisdiction in an action against him personally for money recovery. Id. at 355 .

92. This reasoning is more explicit in People ex rel. Hoagland v. Streeper, 145 N.E.2d 625 (Ill. 1957), where the court observed: "Petitioner seems more to seek the abregation by Illinois of its own sovereignty than the comitas recognition of the sovereignty of Missouri." See also the comments of Lauterpacht quoted in text accompanying note 68 supra.

93. See Florida State Hosp. v. Durham Iron Co., 194 Ga. 350, 21 S.E.2d 216 (1942).

94. This alone may destroy the "contract" theory of waiver of immunity under which the forum state could bar the defendant state, but in return for permitting it to enter the defendant state nust agree to waive immunity. 
nize foreign decrees which it feels are overreaching. Among the United States, however, due process limits the extension of state power and the full faith and credit clause ${ }^{95}$ requires the recognition of decrees within the power of the states. These facts argue for constitutional determination of the foreign immunity.

\section{Federalism Reconsidered}

The full faith and credit clause of the Constitution makes the judgments of one state enforeceable in the courts of another. This clearly distinguishes the problem of interstate sovereign immunity from that of international sovereign immunity since immunity from execution of judgnuent remains a prevailing feature of international sovereignty. ${ }^{90}$ If restrictive sovereign immumity apphies among the Umited States, then the full faith and credit clause may transform state sovereign immunity into a question of federalism. ${ }^{97}$

Though implemented by a federal statute ${ }^{88}$ the full faith and credit clause has been regarded as self-executing. ${ }^{99}$ The statute, which apparently neither adds nor detracts from the effect of the constitutional provision, has not figured prominently in decisions involving the clause. If this clause applies to judgments against states, then all states must give the judgnient the same effect it has in the state where it was rendered. But what effect does such a judgment have in the state where rendered?

The problems of enforcing a judgment against a state have arisen in the context of suits on origmal jurisdiction before the Supreme Court. $^{100}$ Despite excellent commentary, ${ }^{101}$ the question remains

95. Full Faith and Credit shall be given in each State to the public Acts, Records, and Judicial Proceedings of every other State. And the Congress may by general laws prescribe the manner in which such Acts, Records and Proceedings shall be proved, and the Effect thereof.

U.S. CONST. art. IV, $\$ 1$.

96. See note 39 supra.

97. "By the full faith and credit clause our forefathers sought to federalize the separate and independent state legal systems by the overriding principle of reciprocal recognition of public acts, records, and judicial proceedings." Jackson, Full Faith and Credit -The Lawyer's Clause of the Constitution, 45 Colum. L. REv. 1, 17 (1945).

98. 28 U.S.C. $\$ 1738$ (1964) states:

Such Acts, records and judicial proceedings [of any court of any State, ritory or Possession of the United States] or copies thereof, so authenticated, shall have the same full faith and credit in every court within the United States and its Territories and Possessions as they have by law or usage in the courts of such State, Territory, or Possession from which they are taken.

99. In Bradford Electric Light Co. v. Clapper, 286 U.S. 145 (1932), the Court ignored the omission of the words "public acts" from the statute implcmenting the clause and held that full faith and credit must be given to sister state legislation. The statute was amended in 1948 to include the word "Acts."

100. E.g., Virginia v. West Virginia, 206 U.S. 290 (1907). For a summary of the 
fraught with difficulties. For example, state funds cannot be seized unless held in private proprietorship; a writ of mandamus has been used to compel county or municipal officials to levy taxes, but the Court cannot itself levy and collect taxes to satisfy a judgment. ${ }^{102}$ Indeed, mandamus has never been issued against state officials to satisfy judgments. In Kentucky $v$. Dennison, ${ }^{103}$ the Court held that it could not force a state official (the governor) to discharge his duties. In South Dakota v. North Carolina, ${ }^{104}$ the Supreme Court asserted that judgments rendered against a state by the Supreme Court can be enforced even though the Court cannot compel the legislature to levy taxes. But in that case, a mortgage foreclosure sufficed to satisfy judgment, so that no deficiency judgment against the state was required. In Virginia $v$. West Virginia, ${ }^{105}$ the Court agam asserted the enforceability of its judgments against states, but did not indicate how the judgments would be enforced. Fortunately, judgment was eventually satisfied by a West Virginia act. ${ }^{108}$

In suits between states before the United States Supreme Court the power of the executive branch of the federal government may be invoked to enforce a judgment. This enforcement might be aided by congressional legislation. In a case such as Hall, however, access to federal courts, and hence federal enforcement powers, may be precluded by the eleventh amendment, which removes federal jurisdiction over suits brought by a citizen of one state against another state.

The judgment creditor, then, may have to rely upon the courts of the defendant state to enforce his judgment. ${ }^{107}$ Simce the full faith and credit clause has not been used to extend the effect of judgments nuuch beyond their res judicata effect, the law of the enforcement state, here

nine appearances in the U.S. Reports see P. Bator, P. MishikIN, D. SHapIRo \& H.

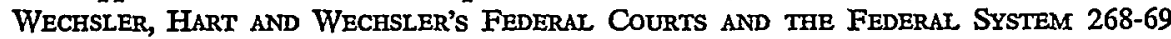
(2d ed. 1973).

101. See Colemnan, The State as Defendant under the Federal Constitution; The Virginia-West Virginia Debt Controversy, 31 HaRv. L. Rev. 210 (1917); Powell, Coercing a State to Pay a Judgment: Virginia v. West Virginia, 17 MrCH. L. Rev. 1 (1918); Fischer, Enforcement of a Money. Judgment Against a State, 12 ST. LouIS L.J. 57 (1927).

102. See Powell, Coercing a State to Pay a Judgment: Virginia v. West Virginia, 17 Micr. L. REv. 1, 6 (1918); see also cases cited in Rees v. City of Watertown, 86 U.S. (19 Wall.) 107, 117-19 (1873).

103. 2 U.S. (2 Dall.) 419 (1793).

104. 192 U.S. 286 (1904).

105. 206 U.S. 290. (1907).

106. Ch. 10 [1914] W. Va. Acts Ext. Sess. 19.

107. The defendant state may have property located in a state other than the state rendering judgment. In this instance, the creditor can execute judgment against such property, relying upon the sister state to provide a remedy. Plaintiff, however, must still obtain jurisdiction over the defendant state. See text accompanying note 93 supra. 
the defendant, largely governs enforcement proceedings. Might the debtor state defeat enforcement by the simple expedient of removing jurisdiction from its courts over such actions? It has been argued in another context that certain constitutional rights may not be defeated by removal of a forum, and that if Congress (or the Constitution, as in the case at issue) removed such jurisdiction from federal courts, state courts would be required to provide a forum. ${ }^{108}$ Does the full faith and credit clause provide such a constitutional right? There is no constitutional right to sue a state. ${ }^{108}$ Arguably, therefore, refusal to allow enforcement is not an abridgment of the judgment creditor's rights. On the other hand, once he has his judgment, a creditor can claim that demal of enforcement deprives him of what have become property rights, in violation of the due process clause of the fourteenth amendment. ${ }^{110}$

Enforcement problems remain even assuming that the full faith and credit clause apphes to judgments against states. What would it mean for a Nevada court to enter judgment against Nevada? How can it force its own unconsenting legislature to pay? Of course, these ultimate questions have not yet been reached in suits between states, but the fact that Congress and the executive branch of the United States were authorized to carry into effect the decree of the Supreme Court in Virginia $v$. West Virginia may have exerted more persuasive pressure on West Virginia to settle than will be present in suits such as Hall $v$. Nevada in the absence of federal jurisdiction.

\section{IV}

\section{SYNTHESIS}

A careful reading of the California Supreme Court's opimion in Hall $v$. Nevada reveals several difficulties. The court failed to examine adequately the questions of federalism raised by Hall.

Further examination has uncovered a line of argument which supports the result in Hall. Even the international law doctrime of restrictive sovereign immunity, however, leaves unresolved problems of enforcement and federalisin. Consideration of what law-state or fed-

108. See generally. Hart, The Power of Congress to Limit the Jurisdiction of Federal Courts: An Exercise in Dialectic, 66 HaRv. L. Rev. 1362 (1953). Hart views Testa v. Katt, 330 U.S. 386 (1947) and General Oil Co. v. Crain, 209 U.S. 211 (1908), as lending support to this position. Id. at 1364 .

109. "The right of an individual to sue a State, in . . . a state court, cannot be derived from the Constitution or laws of the United States." Palmer v. Ohio, 248 U.S. 32, 34 (1918). See also Beers v. Arkansas, 61 U.S. (20 How.) 527 (1857).

110. However, in Beers v. Arkansas, 61 U.S. (20 How.) 527 (1857), the Court upheld the dismissal of a suit brought by a creditor who had relied on a statutory waiver of immunity which had then been repealed. 
eral-should govern the substantive rights at issue may suggest a resolution.

The law regarding interstate disputes between states provides a useful analogy. Article III of the Constitution provides that the Supreme Court will have original jurisdiction in suits between states; Congress has provided exclusive jurisdiction. ${ }^{111}$ Unlike jurisdiction over suits by individuals against states, interstate jurisdiction, considered a necessity, "received not a breath of opposition."112 The exercise of this jurisdiction may have averted doinestic armed conflicts on more than one occasion. ${ }^{113}$

In the absence of any other source of law governing interstate disputes, the Court, drawing upon the principles of international law, ${ }^{114}$ develops its own rules. ${ }^{115}$ Thus, one state cannot subject another state to its law with respect to its own rights. Since soine of the cases between states before the Supreme Court involved questions in which the law of neither state could govern, federally fashioned principles of law had to apply. ${ }^{116}$ Other cases, however, involved the recovery of bond indebtedness, ${ }^{117}$ damages caused by flooding, ${ }^{118}$ breach of contract, ${ }^{119}$ where presumably state law would have governed had the defendant not been a state. ${ }^{120}$ Existing state law did not apply because of the interstate nature of the dispute.

111. 28 U.S.C. $\$ 1251(1)$ (1970).

112. WARREN 33.

113. U.S. CONST. art. I, $\S 10$ forbids the states to "engage in war", and U.S. CoNST. art. IV, $\S 4$ guarantees that "the United States . . . shall protect each [state] against invasion; and . . . against domestic violence."

One cominentator notes:

Evidencing the seriousness of some of these disputes is the fact that in at least four instances-New Jersey v. New York in the 1820's; Missouri v. Iowa in the 1840's; Louisiana v. Mississippi in the 1900's; and Oklahoma v. Texas in very recent years, armed conflicts between the militia or citizens of the contending States had been a prelude to the institution of the suits in the Court. And in several of the other suits, a state of facts was presented which, if arising between independent nations, might well have been a cause for war.

See WARREN 58.

114. W.H. Taft, United States Supreme Court, the Prototype of a World Court, in amtrican Society for Judicial Settlement of International Disputes, Pub. No. 21 (1951), quoted in WARREN 153 n.70.

115. In Illinois v. Milwaukee, 406 U.S. 91 (1972), the Court held that since federal common law governed such disputes between the states, there was federal question jurisdiction, and remitted the case to a federal district court.

116. Boundary disputes provide an example. Note that this same law governs in suits agamst defendants who are not states. Illinois v. Milwaukee, 406 U.S. 91 (1972); Hillnderlider v. La Plata River and Cherry Creek Ditch Co., 304 U.S. 92 (1938).

117. South Dakota v. North Carolina, 192 U.S. 286 (1904).

118. North Dakota v. Minnesota, 263 U.S. 365 (1923).

119. Kentucky v. Indiana, 281 U.S. 163 (1930).

120. "[W]hile the muncipal law relating to like questions between individuals is 
Though none of these cases involved intentional activities of one state within another-as in Hall-the interstate nature of the conflict common to the situations provides an analogy to Hall. Where one state takes jurisdiction over another the tension between the two states exceeds that in the typical conflict of laws situation. In Hall, rather than simply frustrating a policy of Nevada, California could enter judgment against her. This parallels the disputes between states in which the Supreme Court applies federal law and, thus, federal law should similarly govern the Hall situation.

If federal common law governed the substantive disposition of interstate suits, then federal question jurisdiction would extend to them. Unfortunately, the eleventh ainendment removes that jurisdiction. State courts, then, would have to apply federal law. Maintaining uniform application of the vague principles of international law or fundamental principles of justice would be exceedingly difficult. Inevitably, the state court would be influenced by state law. Worse, the lack of clear legal standards in a state court proceeding against a sister state could raise suspicions concerning the impartiality of the result. Hence, defendant states might prefer to waive their eleventh amendment privilege and remove the action to federal court rather than suffer the imdignity or the risk of state court adjudication. ${ }^{121}$

In federal court the problems of enforcement and of interpretation of the full faith and credit clause ${ }^{122}$ would be obviated. Indeed, a federal law governing these controversies argues for some enforcement power under the full faith and credit clause.

to be taken into account, [in determining suits between states], it is not deemed to have controlling weight." Connecticut v. Massachusetts, 282 U.S. 660, 670 (1931).

121. Remnoval could not be based on diversity jurisdiction because a state is not a citizen of a state. Stone v. South Carolina, 117 U.S. 430 (1886). But removal by an individual who was being sued by a state was allowed on the basis of federal questions raised in the suit. Ames v. Kansas, 111 U.S. 449 (1884). Of course, if federal law governed suits such as Hall, such jurisdiction would be supplied if the jurisdictional amount requirement is met.

122. See text accompanying notes $96-110$ supra. 